\title{
Evaluation of phytotherapy alternatives for controlling Rhipicephalus (Boophilus) microplus in vitro
}

\author{
Avaliação de alternativas fitoterápicas no controle in vitro de Rhipicephalus (Boophilus) microplus \\ José Pablo Villarreal Villarreal ${ }^{1 *}$; Pedro Rassier dos Santos ${ }^{1}$; Maria Antonieta Machado Pereira da Silva ${ }^{1}$; \\ Rosaria Helena Machado Azambuja²; Carolina Lambrecht Gonçalves ${ }^{1}$; Jesus Jaime Hernández Escareño ${ }^{3}$; \\ Tânia Regina Bettin dos Santos ${ }^{4}$; Claudio Martin Pereira de Pereiras'; Rogério Antonio Freitag ${ }^{6}$; \\ Patrícia da Silva Nascente ${ }^{1}$
}

\begin{abstract}
${ }^{1}$ Departamento de Microbiologia e Parasitologia, Universidade Federal de Pelotas - UFPel, Pelotas, RS, Brasil
${ }^{2}$ Departamento de Fitosssanidade, Faculdade de Agronomia, Universidade Federal de Pelotas - UFPel, Pelotas, RS, Brasil

${ }^{3}$ Departamento de Microbiología, Facultad de Medicina Veterinaria y Zootecnia, Universidad Autónoma de Nuevo León - UANL, Escobedo, NL, México

${ }^{4}$ Departamento de Veterinária Preventiva, Faculdade de Veterinária, Universidade Federal de Pelotas - UFPel, Pelotas, RS, Brasil

${ }^{5}$ Instituto de Química e Geociências, Universidade Federal de Pelotas - UFPel, Pelotas, RS, Brasil

${ }^{6}$ Departamento de Química Orgânica, Universidade Federal de Pelotas - UFPel, Pelotas, RS, Brasil
\end{abstract}

Received February 1, 2017

Accepted July 25, 2017

\begin{abstract}
The objective of this study was to identify the main chemical components of the essential oil of Cuminum cyminum $\mathrm{L}$. (cumin) and of the fixed oils of Bertholletia excelsa (Brazil nut) and of Helianthus annuus (sunflower seed). As well as testing the three oils and three different commercial synthetic acaricides against engorged females of Rhipicephalus (Boophilus) microplus in order to explore their acaricidal efficacy. Six different concentrations of the oils (200, 100, 50, $25,12.5$ and $6.25 \mathrm{mg} / \mathrm{mL}$ ) and the active principles were evaluated with the Adult Immersion Test (AIT). The two main chemicals components of C. cyminum L. were the cuminaldehyde and the $\gamma$-terpinene. In both $B$. excelsa and $H$. annuиs were the linoleic and oleic acid. C. cyminum L. showed high acaricidal activity (100\%) over the engorged females and on their reproductive characteristat from the concentration of $100 \mathrm{mg} / \mathrm{mL}$. B. excelsa and H. annuus had low acaricidal activity (39.39\% and $58.75 \%$ in the concentration of $200 \mathrm{mg} / \mathrm{mL}$ respectively). The amidine and the pyrethroid (35.12\% and $1.50 \%$ respectively). It can be concluded that the oil of C. cyminum L. may be a phytoterapic alternative for the cattle's tick control.
\end{abstract}

Keywords: Cuminum cyminum L., Bertholletia excelsa, Helianthus annuus, acaricides, tick.

\section{Resumo}

O objetivo do presente estudo foi identificar os componentes químicos majoritários do óleo essencial de Cuminum cyminum L. (comino) e dos óleos fixos de Bertholletia excelsa (castanha do Brasil) e de Helianthus annuus (semente de girassol). Assim como testar os três óleos e três diferentes acaricidas comerciais sintéticos contra fêmeas ingurgitadas de Rhipicephalus (Boophilus) microplus, para explorar sua eficácia acaricida. Seis concentraçôes dos óleos $(200,100,50,25,12,5$ and 6,25 mg/mL) e os princípios ativos foram avaliados por meio do Teste de Imersão de Adultas (AIT). Os dois componentes químicos majoritários de C. cyminum L. foram o cuminaldeído e o y-terpineno. Nos óleos de $B$. excelsa e $H$. annuus os componentes majoritários foram o ácido linoleico e oleico, respectivamente. C. cyminum L. mostrou alta atividade acaricida (100\%) sobre as fêmeas ingurgitadas e suas caraterísticas reprodutivas, a partir da concentraçáo $100 \mathrm{mg} / \mathrm{mL}$., tornando-se uma fonte alternativa para controlar o carrapato do gado. No entanto sao necessários estudos adicionais, a serem conduzidos in vivo. B. excelsa e H. annuus tiveram baixa atividade acaricida (39,39\% e 58,75\% na concentraçáo de $200 \mathrm{mg} / \mathrm{mL}$ respectivamente), não obstante apresentaram maior efeito que a amidina e o piretroide $(35,12 \%$ e $1,50 \%$ respetivamente). Pode-se concluir que o óleo de C. cyminum pode ser uma alternativa fitoterápica para o controle do carrapato do gado.

Palavras-chave: Cuminum cyminum L., Bertholletia excelsa, Helianthus annuus, acaricidas, carrapato.

*Corresponding author: José Pablo Villarreal Villarreal. Departamento 


\section{Introduction}

The direct effects caused by the tick species Rhipicephalus (Boophilus) microplus (Canestrini, 1888) and the agents for bovine babesiosis and anaplasmosis that it transmits are extremely important and have high economic impact on livestock worldwide (JONGEJAN \& UILENBERG, 2004; JONSSON, 2006; RODRIGUEZVIVAS et al., 2017). In Brazil the annual economic losses range from US\$ 800 million to more than 3 billion (GRISI et al., 2014). This tick species is highly prevalent in tropical and subtropical regions, where high relative humidity soils and high temperature weather favor tick population survival (RODRIGUEZ-VIVAS et al., 2006; ESTRADA-PEÑA et al., 2006). In the southern region of Brazil, three to four tick generations are produced per year (PEREIRA et al., 2008b).

It is known that tick control is done mainly through synthetic acaricides worldwide. In Brazil the active agent amidine (Amitraz) and cypermethrin are the ones that have been used most over the last decade (SANTOS \& VOGEL, 2012). The onset of resistance to synthetic acaricides exhibited by $R$. (B.) microplus has given rise to serious problems within cattle production worldwide, such as México, Africa, US and New Caledonia, between others countries (RODRÍGUEZ-VIVAS et al., 2017; VUDRIKO et al., 2016; CHEVILLON et al. 2007; ABBAS et al., 2014). This resistance has developed mainly because of intrinsic or biological factors related to the tick, such as production of genetic mutations in the dominant resistance allele and changes to enzyme metabolism in tick populations (GUERRERO et al., 2001; FOIL et al., 2004). These have occurred through operational factors related to human action aimed towards tick control, and this phenomenon has appeared because producers have used synthetic acaricides as the only tool for controlling this ectoparasite. Moreover, these control measures have commonly been used erroneously, such as excessive use of acaricides without knowledge of tick biology, ecology and prevalence, as well as failure to detect resistance (DENHOLM \& ROWLAND, 1992).

Research efforts have been conducted towards the obtaintion of other therapeutic options in order to solve this problem. These investigations have focused on using botanical compounds and products for controlling $R$. (B.) microplus. In this context, studies have shown that plant-based oils and extracts have been gaining ground as control methods for $R$. (B.) microplus (SANTOS et al., 2013a; BARBOSA et al., 2013). The essential oil of Cuminum cyminum L. (Apiaceae) (cumin) shows antibacterial action (DERAKHSHAN et al., 2010), antifungic activity against fungus resistant to fluconazole (RABADIA et al., 2011) and insecticide activity (YEOM et al., 2012). It has been demonstrated its acaricidal activity against larvae of $R$. (B.) microplus (MARTINEZ-VELAZQUEZ et al., 2011), but its acaricidal activity against engorged female of $R$. (B.) microplus, as well as in their reproductive characteristics is unknown. Several studies using Bertholletia excelsa (Lecythidaceae) (Brazil nut) had demonstrated a tripanocidal activity and a bioactivity against Plasmodium falciparum (KLUCZKOVSKI et al., 2015; CAMPOS et al., 2005; SOUSA, 2013). Studies with the fixed oil of Helianthus annuus (Asteraceae) (sunflower seed) demonstrated an in vitro antimicrobial activity (ABOKI et al., 2012; TABASSUM
\& VIDYASAGAR, 2014) and insecticidal activity against Callosobruchus maculatus, reducing viable eggs and emerged insects (PEREIRA et al., 2008a). No reports were found in the literature about the fixed oil of Bertholletia excelsa (Brazil nut) and of Helianthus annuus (sunflower seed), or fixed oils in general, having any acaricide effect against $R$. (B.) microplus. The yield of these fixed oils is high, and they can be greatly produced in Brazil due to the high availability of these plants.

Given the above, the aim of the present work was: 1) to identify the main chemical components of the Cuminum cyminum $\mathrm{L}$. (cumin) essential oil, Bertholletia excelsa (Brazil nut) and Helianthus annuus (sunflower seed) fixed oils; 2) evaluate oils and commercial synthetic acaricides against engorged females of $R$. (B.) microplus and their reproductive characteristics, in order to explore their acaricidal efficacy.

\section{Materials and Methods}

\section{C. cyminum L.}

\section{Essential oil obtention}

The essential oil was processed in the Laboratório de Pesquisa em Produtos Naturais (LPPN) of the Centro de Ciências Quimicas, Farmacêuticas e de Alimentos (CCQFA) of the Universidade Federal de Pelotas (UFPel), ubicated in the municipality of Capão do Leâo in the state of Rio Grande do Sul, Brazil. The dry seeds of Cuminum cyminum L. used for the obtention of the oil were purchased from the producer Luar Sul ${ }^{\circledR}$ in Rio Grande do Sul, Brazil. The oil was obtained by means of hydrodistillation $(1.5 \mathrm{~L}$ of distilled $\mathrm{H}_{2} \mathrm{O} / 100 \mathrm{~g}$ of plant material) using a Clevenger apparatus. Once the volatile oil was obtained, it was separated from the water, dried with $\mathrm{Na}_{2} \mathrm{SO}_{4}$ sodium sulfate and stored in an amber bottle under refrigeration (RODRIGUES et al., 2004).

\section{Chromatographic analyses}

The analyses was made at the Laboratorio de Lipodômica e Bio-organicâ (LipBio) of the UFPel. The identification of the cumin essential oil was done using a gas chromatograph attached to a mass detector, model GC/MS-QP 2010SE (Shimadzu, Japan), equipped with an AOC-20i auto-injector. The separation occurred in a RTX-5MS (Restek, USA) capillary column; quantification was done by standard area and the compounds identification by the mass spectrometer, using the NIST 8 library of the definer GC/MS. The oil sample was diluted with hexane (analytic degree, ultra pure) (RODRIGUES et al., 2004).

\section{B. excelsa and $H$. annuus}

\section{Fixed oils obtention}

Both the Fixed oils of $B$. excelsa and $H$. annuus were processed in the LLipBio of the CCQFA of the UFPel. The nuts of B. excelsa used for the obtention of the oil were purchased from the producer 
Castanhas of Rondônia ${ }^{\circledR}$ in Rondônia, Brazil and the dry seeds of $H$. annuus used for the obtention of the oil were purchased from the producer Argensun ${ }^{\circledR}$ in Buenos Aires, Argentina. Both fixed oils had the same process of obtention separately. The process consisted in the milling of the nuts and seeds samples in a Willey model B-602 cutting mill, further drying in an oven at $45^{\circ} \mathrm{C}$, followed by extraction where $50 \mathrm{~g}$ of the sample and $300 \mathrm{~mL}$ of hexane solvent were collocated in a Soxhlet apparatus at a temperature of $60^{\circ} \mathrm{C}$ for a 6 -hour period. At the end of the process, the solvent was removed through a route evaporator and the oil stored in an amber bottle under refrigeration.

\section{Preparation of Fatty Acid Methyl Esters (FAMEs) of the fixed oils}

The fixed oils of $B$. excelsa and $H$. annuus had the same preparation process of FAMEs separately. The fatty acids of each fixed oil were converted to their methyl esters using the boron trifluoride-methanol $\left(\mathrm{BF}_{3}\right)$ method, as shown in the literature (MOSS et al., 1974). The resulting mixture of fatty acid methyl esters (FAMEs) in hexane/chloroform (4:1, v/v) was subjected to gas chromatography-flame ionization detection (GC-FID).

\section{Fixed oils (FAMEs) analysis by Gas-chromatography}

Both B. excelsa and H.annuus fixed oils had the same FAMEs analyses separately, performed at the LLipBio of the UFPel. The quantitative GC analyses were performed according to the following conditions using a gas chromatograph GC/FID-2010 with an AOC-20i autosampler (Shimadzu Corporation, Kyoto, Japan) equipped with a fused-silica capillary column (Rtx-WAX, $30 \mathrm{~m} \times 0.25 \mathrm{~mm}$ I.D. $\times 0.25 \mu \mathrm{m}$ film thickness). Injections were performed with a 1:25 split ratio, and hydrogen was used as the carrier gas under constant flow mode at $1.2 \mathrm{~mL} / \mathrm{min}$. The injector was heated to $250^{\circ} \mathrm{C}$, and the flame-ionization detector operated at $250^{\circ} \mathrm{C}$. The initial programmed oven temperature was $100^{\circ} \mathrm{C}$, which was increased by $7^{\circ} \mathrm{C} / \mathrm{min}$ up to $200{ }^{\circ} \mathrm{C}$, then increased by $5^{\circ} \mathrm{C} / \mathrm{min}$ to $202.6^{\circ} \mathrm{C}$ and held isothermal for $2 \mathrm{~min}$ at this temperature. It was then increased by $5{ }^{\circ} \mathrm{C} / \mathrm{min}$ to $222.9^{\circ} \mathrm{C}$ and held isothermal for $2 \mathrm{~min}$, and then increased by $5^{\circ} \mathrm{C} / \mathrm{min}$ to $230{ }^{\circ} \mathrm{C}$ and held isothermal for $10 \mathrm{~min}$ at $230{ }^{\circ} \mathrm{C}$ (TANG \& ROW, 2013). The internal standard solution, containing nonadecanoate methyl ester (C19:0 $\geq 99.0 \%$; Sigma-Aldrich, St. Louis, Missouri, USA), was prepared at a concentration of $2 \mathrm{mg} / \mathrm{mL}$ by dissolving $20 \mathrm{mg}$ methyl nonadecanoate in $10 \mathrm{~mL}$ of n-hexane in a volumetric flask.

\section{Acaricides}

Three acaricides were selected based on the products most commonly used in the region. 1) Clipatic ${ }^{\circledR}$ (Batch number: 016/14, Expiration date. Ago/14-17), Active ingredient: Amitraz, Concentration: $0.125 \mathrm{mg} / \mathrm{mL}$ from Fagra Company. 2) Cyperbio ${ }^{\circledR}$ (Batch number: 002/15, Expiration date. Mar/15-Mar/17), Active ingredient: Cypermethrin, Concentration: $0.150 \mathrm{mg} / \mathrm{mL}$ from
Biofarm Company. 3) Colosso FC30 ${ }^{\circledR}$ (Batch number: 0001/14, Expiration date. Mai/14-16), Active ingredient: Chlorpyrifos + Cypermethrin + Fenthion, Concentration: $0.300 \mathrm{mg} / \mathrm{mL}$, $0.150 \mathrm{mg} / \mathrm{mL}$ and $0.150 \mathrm{mg} / \mathrm{mL}$ respectively from Ourofino Company.

\section{Tick collection}

A population of around 600 engorged females of $R$. (B.) microplus was collected from a beef cattle ranch, situated in the municipality of Capão do Leão located on the southeastern slope of the state of Rio Grande do Sul in Brazil. The engorged females of $R$. (B.) microplus were collected directly from the cattle's bodies, naturally infested and with at least 40 days without acaricide treatment. The engorged females were subjected to further analysis to the Laboratório de Doenças Parasitarias (LADOPAR) in the Faculdade de Veterinaria of the UFPel.

\section{In vitro assay (Adult Immersion Test)}

The adult immersion test (AIT) described by Drummond et al. (1973) was performed. The population of engorged females of $R$. (B.) microplus were selected according to their state, discarding the dead, deformed, altered and hemorrhagic ones. Once the ticks were washed in distilled water and dried in filter paper, they were weighed and then divided into groups of ten females with homogeneous sizes and weights (weight difference of $\pm 0.2 \mathrm{~g}$ ). The commercial synthetic acaricides were diluted in water in accordance with the manufacturer's recommendations. For the three oils, six serial concentrations $(200,100,50,25,12.5$ and $6.25 \mathrm{mg} / \mathrm{mL})$ were made using $75 \%$ ethyl alcohol as solvent. Water and $75 \%$ ethyl alcohol were used as controls groups; it has been previously assessed, these solvents do not interfere in the ticks' mortality (CHAGAS et al., 2003). Each test was performed in duplicate, and thus there were a total of 46 groups. Each test group of ten ticks was immersed for five minutes in each treatment, i.e. each diluted acaricide solution, each oil concentration and each control. After immersion, the groups were dried and dorsally fixed using a double-sided tape, on a previously identified Petri dish. The Petri dishes were taken for incubation in a BOD incubator, at a temperature of $27{ }^{\circ} \mathrm{C}$ $\left( \pm 1^{\circ} \mathrm{C}\right)$ and relative humidity higher than $80 \%$, which are the ideal conditions for oviposition. After 14 days of incubation, the mortality rate of the adult females was evaluated and the fertile egg mass of each group was weighed and collocated in a glass vial for incubation in a BOD incubator, under the same conditions; after 30 day the egg hatching analysis was performed.

From these data, the estimated reproduction (ER) and the product effectiveness (PE\%) of the treatments were determinate based on the following Formulas 1 and 2, described by Drummond et al. (1973):

$\mathrm{RE}=$ Reproductive efficiency:

$\mathrm{RE}=($ egg weight $\times \%$ egg hatching $\times 20,000) /$ engorged female weight $(1)$

$\mathrm{PE}=$ Product effectiveness \%:

$\mathrm{PE}=(\mathrm{RE}$ of control group $-\mathrm{RE}$ of treated group $\times 100) / \mathrm{RE}$ of control group 


\section{Statistical analysis}

The mortality rate among engorged females (\%), egg weight (g), hatching rate (\%), as well as the mean efficacy of the products and the oils, were analyzed using the IBM SPSS software V21. Data was checked for normality and homogeneity. As these assumptions were not met, a non-parametric test (Kruskal-Wallis) was used to determine whether there were significant differences among the groups. Intergroup comparison was made using a Wilcoxon-Mann-Whitney test with Bonferroni correction, $\mathrm{p}$ values $<0.05$ were considered statistically significant.

\section{Results and Discussion}

The main chemical components, with isolation proportions greater than $1 \%$ detected by gas chromatography-mass spectrometry of the three oils are shown in Table 1 . The extraction yield for the essential oil of C. cyminum L. was of $2.5 \%$.

The cuminaldehyde, $\gamma$-terpinene and $\beta$-pinene have shown insecticidal activity (PARK et al., 2008; YEOM et al., 2012), as well as a bactericidal activity against Gram-negative and Gram-positive bacteria (IACOBELLIS et al., 2005). In vitro studies have demonstrated the inhibitory and toxic effect of cuminaldehyde due to suffocation and inhibition of a variety of biosynthetic processes that are shown in the beetle's different development stages, such as an effect of inhibiting acetylcholinesterase enzymatic activity (CHAUBEY, 2008; ABDELGALEIL et al., 2009). The acaricidal activity shown in $R$. (B.) microplus tick larvae, of the essential oil of $C$. cyminum L., may be attributable to the high level of cuminaldehyde (22.03\%), $\gamma$-terpinene $(15.69 \%)$ and 2 -caren-10-al $(12.89 \%)$, as well as to minor components, such as the o-cymene and $\beta$-pinene (MARTINEZ-VELAZQUEZ et al., 2011); however, the proportions of cuminaldehyde, $\gamma$-terpinene, $\beta$-pinene and o-cymene obtained in this study were higher, which can explain the acaricidal activity reflected on the results shown in Table 2.

Based on the reproductive characteristics and product effectiveness with the C. cyminum L. (cumin) essential oil (Table 2), it is observed that in general, the acaricidal effect was directly proportional to the concentration. The highest mortalities of the engorged females were at concentrations of $200 \mathrm{mg} / \mathrm{mL}$ and $100 \mathrm{mg} / \mathrm{mL}$ (100\%a in both), at concentration of $50 \mathrm{mg} / \mathrm{mL}$, the mortality decreased to $85 \%^{\mathrm{a}}$, and the lowest mortalities obtained, were at concentrations of $25 \mathrm{mg} / \mathrm{mL}, 12.5 \mathrm{mg} / \mathrm{mL}$ and $6.25 \mathrm{mg} / \mathrm{mL}$ with $45 \%^{\mathrm{b}}, 20 \%^{\mathrm{b}}$ and $20 \%^{\mathrm{b}}$, respectively. All concentrations showed statistical difference with the control. In a study done in Mexico, five concentrations $(20 \%, 10 \%, 5 \%, 2.5 \%$ and $1.25 \%)$ of cumin essential oil were tested in larvae of $R$. (B.) microplus and in all concentrations mortality of $100 \%$ was shown (MARTINEZVELAZQUEZ et al., 2011). However, it is known that larvae are more sensitive than engorged females, as it has been seen in studies with substances of plant origin (BORGES et al., 2011), because the cuticle of the tick is formed of an external layer called epicuticle (made externally of wax and internally of proteins). The layer of wax or lipids is seen only in $R$. (B.) microplus from the ecdise of the nymph and in higher amount in the adult (BALASHOV, 1972; ODHIAMBO, 1982).

Due to the high mortality in the engorged females shown by the two highest concentrations, no weights of the eggs and egg hatching results were obtained. The egg mass weights at concentrations of $50 \mathrm{mg} / \mathrm{mL}, 25 \mathrm{mg} / \mathrm{mL}$ and $12.5 \mathrm{mg} / \mathrm{mL}$ were of $184 \mathrm{mg}, 464 \mathrm{mg}$ and $1085 \mathrm{mg}$ respectively, showing a negative effect $(\mathrm{p}<0.05)$ on the egg posture, when compared to the control (1360 mg). Only the concentration of $6.25 \mathrm{mg} / \mathrm{mL}$, did not show any negative effect on the egg posture regarding the control $(p<0.05)$, with weight of $1247 \mathrm{mg}$. It is worth mentioning that at concentrations of $50 \mathrm{mg} / \mathrm{mL}$ and $25 \mathrm{mg} / \mathrm{mL}$, the egg hatching was below $10 \%$,

Table 1. Main chemical components of Cuminum cyminum L. (Cumin), Bertholletia excelsa (Brazil nut) and Helianthus annuus (Sunflower seed) essential oils.

\begin{tabular}{lccc}
\hline \multicolumn{1}{c}{ Chemical component } & Cuminum cyminum L (\%) & Bertholletia excelsa (\%) & Helianthus annus (\%) \\
\hline Myristic Acid & - & 0.044 & 0.071 \\
Palmitic Acid & - & 13.467 & 5.791 \\
Palmitoleic Acid & - & 0.232 & 0.073 \\
Margaric Acid & - & 0.129 & 0.039 \\
Steric Acid & - & 7.741 & 4.106 \\
Oleic Acid & - & 30.606 & 35.805 \\
Linoleic Acid & - & 47.256 & 53.638 \\
Linolenic Acid & - & 0.095 & 0.043 \\
Arachidic Acid & - & 0.194 & 0.244 \\
Gadoleic Acid & - & 0.07 & 0.096 \\
Behenic acid & - & 0.099 & 0.0866 \\
Lignoceric Acid & - & 0.065 & 0.228 \\
Cuminaldehyde & 32.66 & - & - \\
$\gamma$-terpinene & 19.87 & - & - \\
$\beta$-pinene & 15.22 & - & - \\
O-cymene & 14 & - & - \\
2-caren-10-al & 8.54 & - & - \\
1-phenyl-1-butanol & 8.01 & - & - \\
\hline
\end{tabular}


Table 2. Evaluation of the commercial acaricides and of the six different concentrations of the Cumin essential oil, Brazilian nut and Sunflower seed fixed oils on reproductive indices of $R$. (B.) microplus, as well as their Product effectiveness (values are expressed in mean \pm SD).

\begin{tabular}{|c|c|c|c|c|}
\hline Commercial product & Female mortality $\%$ & $\begin{array}{c}\text { Egg mass weight } \\
(\mathrm{mg})\end{array}$ & Egg Hatching \% & $\begin{array}{c}\text { Product Effectivness } \\
(\%)\end{array}$ \\
\hline Amitraz & $25.00 \pm 21.23^{b}$ & $1110 \pm 0.18^{a}$ & $80.00 \pm 0.0^{b}$ & $35.12 \pm 9.44$ \\
\hline Pyrethtoid & $0.00 \pm 0.0^{\mathrm{c}}$ & $1480 \pm 0.06^{\mathrm{a}}$ & $92.50 \pm 3.54^{\mathrm{a}}$ & $1.50 \pm 2.12$ \\
\hline Organophosphate-Pyrethroid Association & $100.00 \pm 0.0^{\mathrm{a}}$ & $0.00 \pm 0.0^{b}$ & $0.00 \pm 0.0^{\mathrm{c}}$ & $100.00 \pm 0.0$ \\
\hline Water & $5.00 \pm 0.0^{b}$ & $1360 \pm 0.03^{a}$ & $88.75 \pm 1.77^{a}$ & - \\
\hline \multicolumn{5}{|l|}{ Cuminum cyminum $L$} \\
\hline $6.25 \mathrm{mg} / \mathrm{mL}$ & $20.00 \pm 0.0^{\mathrm{b}}$ & $1247 \pm 0.18^{a}$ & $88.75 \pm 1.77^{a}$ & $18.58 \pm 9.69$ \\
\hline $12.5 \mathrm{mg} / \mathrm{mL}$ & $20.00 \pm 14.14^{b}$ & $1085 \pm 0.32^{b}$ & $27.50 \pm 24.75^{b}$ & $74.51 \pm 27.37$ \\
\hline $25 \mathrm{mg} / \mathrm{mL}$ & $45.00 \pm 7.07^{b}$ & $464 \pm 0.02^{c}$ & $7.75 \pm 3.18^{b}$ & $97.34 \pm 1.12$ \\
\hline $50 \mathrm{mg} / \mathrm{mL}$ & $85.00 \pm 21.21^{\mathrm{a}}$ & $184 \pm 0.26^{c}$ & $1.50 \pm 2.12^{b}$ & $99.58 \pm 0.59$ \\
\hline $100 \mathrm{mg} / \mathrm{mL}$ & $100.00 \pm 0.0^{\text {a }}$ & $0.00 \pm 0.0^{\mathrm{c}}$ & $0.00 \pm 0.0^{\mathrm{c}}$ & $100.00 \pm 0.0$ \\
\hline $200 \mathrm{mg} / \mathrm{mL}$ & $100.00 \pm 0.0^{\mathrm{a}}$ & $0.00 \pm 0.0^{\mathrm{c}}$ & $0.00 \pm 0.0^{\mathrm{c}}$ & $100.00 \pm 0.0$ \\
\hline Alcohol & $5.00 \pm 0.0^{c}$ & $1360 \pm 0.06^{\mathrm{a}}$ & $96.00 \pm 0.0^{\mathrm{a}}$ & - \\
\hline \multicolumn{5}{|l|}{ Bertholletia excelsa } \\
\hline $6.25 \mathrm{mg} / \mathrm{mL}$ & $0.00 \pm 0.0^{\mathrm{a}}$ & $1437 \pm 0.08^{a}$ & $91.50 \pm 9.19^{\mathrm{a}}$ & $8.16 \pm 11.54$ \\
\hline $12.5 \mathrm{mg} / \mathrm{mL}$ & $10.00 \pm 14.14^{\mathrm{a}}$ & $1263 \pm 0.25^{a}$ & $93.00 \pm 0.0^{\mathrm{a}}$ & $13.96 \pm 19.74$ \\
\hline $25 \mathrm{mg} / \mathrm{mL}$ & $15.00 \pm 7.07^{\mathrm{a}}$ & $1194 \pm 0.19^{a}$ & $92.00 \pm 2.83^{\mathrm{a}}$ & $19.69 \pm 14.86$ \\
\hline $50 \mathrm{mg} / \mathrm{mL}$ & $25.00 \pm 35.36^{a}$ & $1049 \pm 0.46^{a}$ & $90.00 \pm 7.07^{a}$ & $29.96 \pm 32.92$ \\
\hline $100 \mathrm{mg} / \mathrm{mL}$ & $10.00 \pm 0.0^{\mathrm{a}}$ & $1228 \pm 0.0^{\mathrm{a}}$ & $87.50 \pm 10.61^{a}$ & $20.91 \pm 6.41$ \\
\hline $200 \mathrm{mg} / \mathrm{mL}$ & $25.00 \pm 35.36^{\mathrm{a}}$ & $937 \pm 0.43^{a}$ & $90.00 \pm 7.07^{a}$ & $39.39 \pm 20.70$ \\
\hline Alcohol & $5.00 \pm 0.0^{a}$ & $1360 \pm 0.06^{a}$ & $96.00 \pm 0.0^{\mathrm{a}}$ & - \\
\hline \multicolumn{5}{|l|}{ Helianthus annuus } \\
\hline $6.25 \mathrm{mg} / \mathrm{mL}$ & $5.00 \pm 7.07^{\mathrm{a}}$ & $1425 \pm 0.15^{\mathrm{a}}$ & $96.00 \pm 0.0^{\mathrm{a}}$ & $4.66 \pm 6.60$ \\
\hline $12.5 \mathrm{mg} / \mathrm{mL}$ & $0.00 \pm 0.0^{\text {a }}$ & $1501 \pm 0.0^{\text {a }}$ & $92.00 \pm 2.83^{a}$ & $1.51 \pm 2.14$ \\
\hline $25 \mathrm{mg} / \mathrm{mL}$ & $5.00 \pm 7.07^{a}$ & $1380 \pm 0.15^{a}$ & $88.50 \pm 4.95^{\mathrm{a}}$ & $11.31 \pm 16.00$ \\
\hline $50 \mathrm{mg} / \mathrm{mL}$ & $10.00 \pm 0.0^{\mathrm{a}}$ & $1298 \pm 0.05^{\mathrm{a}}$ & $92.50 \pm 3.54^{\mathrm{a}}$ & $11.48 \pm 3.15$ \\
\hline $100 \mathrm{mg} / \mathrm{mL}$ & $5.00 \pm 7.07^{a}$ & $1230 \pm 0.09^{\mathrm{a}}$ & $92.50 \pm 3.549^{a}$ & $16.24 \pm 0.95$ \\
\hline $200 \mathrm{mg} / \mathrm{mL}$ & $25.00 \pm 7.07^{a}$ & $781 \pm 0.14^{b}$ & $72.50 \pm 10.61^{a}$ & $58.75 \pm 3.29$ \\
\hline Alcohol & $5.00 \pm 0.0^{a}$ & $1360 \pm 0.06^{\mathrm{a}}$ & $96.00 \pm 0.0^{\mathrm{a}}$ & - \\
\hline
\end{tabular}

Common corresponding letters a-c in a given column indicates no significant differences $(\mathrm{p}<0,05)$.

having high negative effect. At concentration of $12.5 \mathrm{mg} / \mathrm{mL}$, the egg hatching went up to $27.50 \%$, but still indicating a negative effect $(\mathrm{p}<0.05)$. Only the concentration of $6.25 \mathrm{mg} / \mathrm{mL}(88.75 \%$ of egg hatching) did not presented statistical significance toward the control (96\%), showing a low effect. The cumin essential oil presented high Product Effectiveness (PE) at concentrations of $200 \mathrm{mg} / \mathrm{mL}, 100 \mathrm{mg} / \mathrm{mL}, 50 \mathrm{mg} / \mathrm{mL}$ and $25 \mathrm{mg} / \mathrm{mL}$, with $100 \%, 100 \%, 99.58 \%$ and $97.34 \%$, respectively, being above the level stipulated in Decree no. 48 of year 1997 from the Ministerio da Agricultura, Pecuaria e Abastecimento (BRASIL, 1997), which states that a product is considered effective as an antiparasitic agent, when the $\mathrm{PE}$ is $\geq 95 \%$, having similar results with the Organophosphate-Pyrethroid Association (Table 2), at concentration of $12.5 \mathrm{mg} / \mathrm{mL}$. The PE decreased to $74.51 \%$ and at concentration $6.25 \mathrm{mg} / \mathrm{mL}$ decreased to $18.58 \%$. The effective results obtained in the engorged female mortality and in the reproductive characteristics, are due to the bioactivity acaricidal effect of the main multiple chemical compounds and by their high percentage amount showed by the gas chromatography-mass spectrometry (Table 1).

The obtained results support that this essential oil as an alternative source to control the cattle tick, delaying the development of resistance; on the other hand, this is only the acaricidal effect in vitro; additional studies conduct in vivo are necessary, applied as pour-on, on the animal's back and/or with aspersion (MARTINS \& GONZÁLEZ, 2007), in order to see if the lowest acaricidal concentration tested in this study, can cause the same activity, due to the difficulties related to external environmental conditions (MULLA \& SU, 1999). Regarding the time of storage and conservation of the oil and the seeds, as seen in others plant extracts (BORGES et al., 2011), as well as to the low yield of the oil, we believe that further studies testingt other types of extracts of the cumin seeds and other parts of the plants should be done, identifing the mode of action of the main bioactive compounds and those minor compounds with synergism, to evaluate their toxicity.

The chromatographic profile of the fixed oil of $B$. excelsa (Brazil nut), showed as the major compounds the unsaturated fatty acids. In the polyunsaturated fatty acids, the linoleic acid (C18:2n6c) was the main component with $47.25 \%$ and in the monounsaturated fatty acids was the oleic acid (C18:1n9c) with $30.60 \%$. The extraction yield of the oil was of $69 \%$, which is high. This results were close to those obtained by Ryan et al. (2006), where they obtained $42.80 \%$ of linoleic acid and $29.09 \%$ of oleic 
acid, as well as those obtained by Venkatachalam \& Sathe (2006), with $45.43 \%$ of linoleic acid and $28.75 \%$ of oleic acid.

The six different concentrations of the fixed oil of $B$. excelsa (Brazil nut), did not show statistical difference with the control ( $p>0.05)$ in the mortalities of the engorged females and on each of the reproductive characteristics, with some of the results not being directly proportional with the concentrations and with variations on the results between them. In the mortality of the engorged females, both concentrations of $200 \mathrm{mg} / \mathrm{mL}$ and $50 \mathrm{mg} / \mathrm{mL}$ showed $25 \%$, the concentration of $12.5 \mathrm{mg} / \mathrm{mL}$ had $15 \%$, at concentrations of $100 \mathrm{mg} / \mathrm{mL}$ and $12.5 \mathrm{mg} / \mathrm{mL}$ the mortality was of $10 \%$ in each, the concentration of $6.25 \mathrm{mg} / \mathrm{mL}$, did not present any mortality in the engorged females. The eggs mass weights were proportional to the mortality of the engorged females at each concentration. The lower egg mass weight was at concentration of $200 \mathrm{mg} / \mathrm{mL}$ with $937 \mathrm{mg}$, the concentration of $100 \mathrm{mg} / \mathrm{mL}$ showed the lowest egg hatching $(87.50 \%)$; however, no statistical difference with the control was seen, having a low effect. The fixed oil presented the higher PE (39.39\%) at the concentration of $200 \mathrm{mg} / \mathrm{mL}$, below the average established by the MAPA.

The results in the chromatographic profile of the fixed oil of $H$. annuus (Sunflower seed), also showed that the unsaturated fatty acids were the main components, with $53.63 \%$ of linoleic acid $(\mathrm{C} 18: 2 \mathrm{n} 6 \mathrm{c})$ and $35.80 \%$ of oleic acid (C18:1n9c). The extraction yield for the oil was of $61 \%$. These results were close to those reported by Mandarino (1992), with 50\% to $70 \%$ of linoleic acid and $26 \%$ to $40 \%$ of oleic acid. In general, the differences in the quantities of the unsaturated fatty acids components of the two fixed oils in this study with those mentioned in the other studies can be related to the origin and genotype of the nuts and seeds.

The fixed oil of $H$. annuus (sunflower seed), like the fixed oil of $B$. excelsa (Brazil nut), obtained results not directly proportional to the concentrations, none of the concentrations showed a statistical difference with the control. The highest mortality (25\%) was at the concentration of $200 \mathrm{mg} / \mathrm{mL}$. At the concentration of $50 \mathrm{mg} / \mathrm{mL}$, the mortality was of $10 \%$, in the concentrations of 100,25 and $6.25 \mathrm{mg} / \mathrm{mL}$ the mortalities were of $5 \%$ and the concentration of $12.5 \mathrm{mg} / \mathrm{mL}$ not showed mortalilty. In the fixed oil of $H$. annuus, the concentration of $200 \mathrm{mg} / \mathrm{mL}$ presented the lowest egg mass weight $(781 \mathrm{mg})(\mathrm{p}<0.05)$; also, this concentration showed the lowest hatching rate with $72.50 \%$ (no statistical difference with the control). Between the fixed oils, this oil presented the higher PE (58.75\%) at the concentration of $200 \mathrm{mg} / \mathrm{mL}$, but below the average established by the MAPA. It is important to establish that in both fixed oils the PEs were higher than those obtained by the pyrethroid and the amidine tested in this study.

In general, both fixed oils showed low mortalities, attributed to the fact that the main components are unsaturated fatty acids (Table 1). Also, they did not have a high acaricidal activity, like the high mortality effect shown in the essential oil. In addition, it can be deduced that the low mortality was because the fixed oils never evaporate or volatilize completely, remaining as viscous liquids. Once in contact for a period of time with the tick's spiracles, where the normal route for gas exchanges through holes or aeropyles and the ambient air is made (HINTON, 1967), the demand for oxygen and release of carbon dioxide is not balanced and excessive water loss occurs, causing suffocation of the tick and consequent dehydratation. Therefore, the variations of the results between the six diferent concentrations may be due to several factors such as the time of contact of the oil after the immersion test in the cuticle in each tick and the misture at dilutions of the oils with the solvent. It is important to menthion that irregularities in mortality were shown in a study with essential oil in the study by Olivo et al. (2008), in which citronella oil (0.5\% and $1 \%)$ was used against engorged adult $R$. (B.) microplus females. Thus, the phenomenon of passivation was observed, where the concentrated product started to be absorbed, but a passivator film began to form, thereby inhibiting passage of the oil. In such situations, the oil therefore penetrates better when it is more diluted, because no protective film has formed, causing higher absorption (CHAGAS et al., 2002).

Plants of the same species can vary in the quantity of chemical compounds due to their interspecific variation and other factors such as seasonality, circadian rhythm, development, temperature, ultraviolet radiation, water availability, altitude and atmospheric pollution, among others; this can coordinate or change the rate of production of the secondary metabolites (GOBBO-NETO \& LOPES, 2007). Generally, the acaricidal effect of an essential oil is attributed to the components isolated in higher quantity; however, the activity of the main compound can be regulated by other components present in minor quantity (CAMPOS et al., 2012).

The reproductive indices and PEs obtained from the three commercial acaricides (Table 2), showed that between the three acaricides, only the organophosphate-pyrethroid association had a product effectiveness of $100 \%$, being above the established by the MAPA. The amidine presented low effectiveness (35.12\%), and the pyrethroid presented the lowest PE (1.50\%) among the acaricides.

\section{Conclusions}

The essential oil of C. cyminum L., demonstrate high acaricidal activity (100\%), in vitro from the concentration of $100 \mathrm{mg} / \mathrm{ml}$, against engorged females of $R$. (B.) microplus. The oil's activity was attributed to the high content of bioactive biodegradables compounds. There is a need for additional studies, to be conduct in vivo. On the other hand, the fixed oils of $B$. excelsa and $H$. annuus had low acaricidal effect $39.39 \%$ and $58.75 \%$ in the concentration of $200 \mathrm{mg} / \mathrm{ml}$ respectively). The amitraz and pyrethroid. Had low acaricidal effect $(35.12 \%$ and $1.50 \%$ respectively), only the association showed high acaricidal effect (100\%).

\section{References}

Abbas RZ, Zaman MA, Colwell DD, Gilleard J, Iqbal Z. Acaricide resistance in cattle ticks and approaches to its management: the state of play. Vet Parasitol 2014; 203(1-2): 6-20. PMid:24709006. http://dx.doi. org/10.1016/j.vetpar.2014.03.006.

Abdelgaleil SAM, Mohamed MIE, Badawy MEI, El-Arami SAA. Fumigant and contact toxicities of monoterpenes to Sitophilus oryzae (L.) and Tribolium castaneum (Herbst) and their inhibitory effects on acetylcholinesterase activity. J Chem Ecol 2009; 35(5): 518-525. PMid:19412756. http:// dx.doi.org/10.1007/s10886-009-9635-3. 
Aboki MA, Mohammed M, Musa SH, Zuru BS, Aliyu HM, Gero $\mathrm{M}$, et al. Physicochemical and anti-microbial properties of sunflower (Helianthus annuus L.) Seed Oil. Int J Sci Technol 2012; 2(4): 151-154.

Balashov YS. A translation of bloodsucking ticks (Ixodoidea) - vectors of diseases of man and animals. Misc Publ Entomol 1972; 8(5): 161-376.

Barbosa CS, Borges LMF, Nicácio J, Alves RD, Miguita CH, Violante IMP, et al. In vitro activities of plant extracts from the Brazilian Cerrado and Pantanal against Rhipicephalus (Boophilus) microplus (Acari: Ixodidae). Exp Appl Acarol 2013; 60(3): 421-430. PMid:23344640. http://dx.doi. org/10.1007/s10493-013-9656-z.

Borges LMF, Sousa LAD, Barbosa CS. Perspectives for the use of plant extracts to control the cattle tick Rhipicephalus (Boophilus) microplus. Rev Bras Parasitol Vet 2011; 20(2): 89-96. PMid:21722481. http://dx.doi. org/10.1590/S1984-29612011000200001.

Brasil. Ministério da Agricultura e Abastecimento - MAPA. Secretaria de Defesa Agropecuária. Portaria no 48, de 12 maio de 1997. Aprova como anexo o Regulamento Técnico a ser observado na produção, no controle e no emprego de antiparasitários de uso veterinário. Diário Oficial da República Federativa do Brasil, Brasília, maio. 1997 [cited 2017 Feb 1]. Available from: http://www.agricultura.gov.br/assuntos/ insumos-agropecuarios/insumos-pecuarios/produtos-veterinarios/legislacao

Campos FR, Januário AH, Rosas LV, Nascimento SK, Pereira PS, França SC, et al. Trypanocidal activity of extracts and fractions of Bertholletia excelsa. Fitoterapia 2005; 76(1): 26-29. PMid:15664458. http://dx.doi. org/10.1016/j.fitote.2004.09.008.

Campos RNS, Bacci L, Araújo APA, Blank AF, Arrigoni-Blank MF, Santos GRAE, et al. Óleos essenciais de plantas medicinais e aromáticas no controle do carrapato Rhipicephalus microplus. Arch Zootec 2012; 61(1): 67-68.

Chagas ACS, Leite RC, Furlong J, Prates HT, Passos WM. Sensibility of Boophilus microplus tick to solvents. Cienc Rural 2003; 33(1): 109-114. http://dx.doi.org/10.1590/S0103-84782003000100017.

Chagas ACS, Passos WM, Prates HT, Leite RC, Furlong J, Fortes ICP. Acaricide effect of Eucalyptus spp essential oils and concentrated emulsion on Boophilus microplus. Braz J Vet Res Anim Sci 2002; 39(5): 247-253. http://dx.doi.org/10.1590/S1413-95962002000500006.

Chaubey MK. Fumigant toxicity of essential oils from some common spices against pulse beetle, Callosobruchus chinensis (Coleoptera: Bruchidae). J Oleo Sci 2008; 57(3): 171-179. PMid:18270466. http:// dx.doi.org/10.5650/jos.57.171.

Chevillon C, Ducornez S, Meeûs T, Koffi BB, Gaïa H, Delathière JM, et al. Accumulation of acaricide resistance mechanisms in Rhipicephalus (Boophilus) microplus (Acari:Ixodidae) populations from New Caledonia Island. Vet Parasitol 2007; 147(3-4): 276-288. PMid:17560723. http:// dx.doi.org/10.1016/j.vetpar.2007.05.003.

Denholm I, Rowland MW. Tactics for managing pesticide resistance in Arthropods: theory and practice. Annu Rev Entomol 1992; 37(1): 91-112. PMid:1539942. http://dx.doi.org/10.1146/annurev.en.37.010192.000515.

Derakhshan S, Sattari M, Bigdeli M. Effect of cumin (Cuminum cyminum) seed essential oil on biofilm formation and plasmid integrity of Klebsiella pneumoniae. Pharmacogn Mag 2010; 6(21): 57-61. PMid:20548937. http://dx.doi.org/10.4103/0973-1296.59967.

Drummond RO, Ernst SE, Trevino JL, Gladney WJ, Graham OH. Boophilus annulatus and B. microplus: laboratory tests of insecticides. J Econ Entomol 1973; 66(1): 130-133. PMid:4690254. http://dx.doi. org/10.1093/jee/66.1.130.
Estrada-Peña A, Bouattour A, Camicas JL, Guglielmone A, Horak I, Jongejan F, et al. The known distribution and ecological preferences of the tick subgenus Boophilus (Acari: Ixodidae) in Africa and Latin America. Exp Appl Acarol 2006; 38(2-3): 219-235. PMid:16596355. http://dx.doi. org/10.1007/s10493-006-0003-5.

Foil LD, Coleman P, Eisler M, Fragoso-Sanchez H, Garcia-Vazquez Z, Guerrero FD, et al. Factors that influence the prevalence of acaricide resistance and tick-borne diseases. Vet Parasitol 2004; 125(1-2): 163181. PMid:15476966. http://dx.doi.org/10.1016/j.vetpar.2004.05.012.

Gobbo-Neto L, Lopes NP. Plantas medicinais: fatores de influência no conteúdo de metabólitos secundários. Quim Nova 2007; 30(2): 374-381. http://dx.doi.org/10.1590/S0100-40422007000200026.

Grisi L, Leite RC, Martins JRS, Barros ATM, Andreotti R, Cançado PHD, et al. Reassessment of the potential economic impact of cattle parasites in Brazil. Rev Bras Parasitol Vet 2014; 23(2): 150-156. PMid:25054492. http://dx.doi.org/10.1590/S1984-29612014042.

Guerrero FD, Davey RB, Miller RJ. Use of an allele-specific polymerase chain reaction assay to genotype pyrethroid resistant strains of Boophilus microplus (Acari: Ixodidae). J Med Entomol 2001; 38(1): 44-50. PMid:11268690. http://dx.doi.org/10.1603/0022-2585-38.1.44.

Hinton HE. The structure of the spiracles of the cattle tick, Boophilus microplus. Aust JZool 1967; 15(5): 941-949. http://dx.doi.org/10.1071/ ZO9670941.

Iacobellis NS, Lo Cantore P, Capasso F, Senatore F. Antibacterial activity of Cuminum cyminum L. and Carum carvi L. essential oils. J Agric Food Chem 2005; 53(1): 57-61. PMid:15631509. http://dx.doi.org/10.1021/ jf0487351.

Jongejan F, Uilenberg G. The global importance of ticks. Parasitology 2004;129(S1 Suppl): S3-S14. PMid:15938502.

Jonsson NN. The productivity effects of cattle tick (Boophilus microplus) infestation on cattle, with particular reference to Bos indicus cattle and their crosses. Vet Parasitol 2006; 137(1-2): 1-10. PMid:16472920. http:// dx.doi.org/10.1016/j.vetpar.2006.01.010.

Kluczkovski AM, Martins M, Mundim SM, Simôes RH, Nascimento KS, Marinho HA, et al. Properties of Brazil nuts: a review. Afr J Biotechnol 2015; 14(8): 642-648. http://dx.doi.org/10.5897/AJB2014.14184.

Mandarino JMG. Caracteristicas bioquímicas e nutricionais do óleo e do farelo de girassol. Londrina: EMBRAPA-CNPSo; 1992.

Martinez-Velazquez M, Castillo-Herrera GA, Rosario-Cruz R, FloresFernandez JM, Lopez-Ramirez J, Hernandez-Gutierrez R, et al. Acaricidal effect and chemical composition of essential oils extracted from Cuminum cyminum, Pimenta dioica and Ocimum basilicum against the cattle tick Rhipicephalus (Boophilus) microplus (Acari: Ixodidae). Parasitol Res 2011; 108(2): 481-487. PMid:20865426. http://dx.doi.org/10.1007/s00436010-2069-6.

Martins RM, González FHD. Uso del aceite de citronela de Java (Cymbopogon winterianus Jowitt) (Panicoidideae) como acaricida frente a la garrapata Boophilus microplus Canestrini (Acari: Ixodidae). Rev Bras Pl Med 2007; 9(4): 1-8.

Moss CW, Lambert MA, Merwin WH. Comparison of rapid methods for analysis of bacterial fatty acids. Appl Microbiol 1974; 28(1): 80-85. PMid:4844271.

Mulla MS, Su T. Activity and biological effects of neem products against arthropods of medical and veterinary importance. J Am Mosq Control Assoc 1999; 15(2): 133-152. PMid:10412110.

Odhiambo TR. Current themes in tropical science: physiology of ticks. Oxford: Pergamon; 1982. 
Olivo CJ, Carvalho NM, Silva JHS, Vogel FF, Massario P, Meinerz G, et al. Citronella oil on the control of cattle ticks. Cienc Rural 2008; 38(2): 406-410. http://dx.doi.org/10.1590/S0103-84782008000200018.

Park IK, Kim JN, Lee YS, Lee SG, Ahn YJ, Shin SC. Toxicity of plant essential oils and their components against Lycoriella ingenua (Diptera: Sciaridae). J Econ Entomol 2008; 101(1): 139-144. PMid:18330128. http://dx.doi.org/10.1093/jee/101.1.139.

Pereira ACRL, Oliveira JV, Gondim MGC Jr, Câmara CAG. Atividade inseticida de óleos essenciais e fixos sobre Callosobruchus maculatus (Fabr, 1775) (Coleoptera: Bruchidae) em grãos de caupi [Vigna unguiculata (L.) Walp.]. Cienc Agrotec 2008a; 32(3): 717-724. http://dx.doi.org/10.1590/ S1413-70542008000300003.

Pereira MC, Labruna MB, Szabó MPJ, Klafke GM. Rhipicephalus (Boophilus) microplus: Biologia, Controle e Resistência. São Paulo: MedVet; 2008b.

Rabadia AG, Kamat S, Kamat D. Antifungal activity of essential oils against Fluconazole resistant fungi. Int J Phytomed 2011; 3(4): 506-510.

Rodrigues MRA, Krause LC, Caramão EB, Santos JG, Dariva C, Oliveira JV. Chemical composition and extraction yield of the extract of Origanum vulgare obtained from sub- and supercritical CO2. J Agric Food Chem 2004; 52(10): 3042-3047. PMid:15137851. http://dx.doi. org/10.1021/jf030575q.

Rodríguez-Vivas RI, Grisi L, León AAP, Villela HS, Torres-Acosta JF, Sánchez HF, et al. Potential economic impact assessment for cattle parasites in Mexico. Rev Mex De Cienc Pecu 2017; 8(1): 61-74. http:// dx.doi.org/10.22319/rmcp.v8i1.4305.

Rodríguez-Vivas RI, Rodríguez-Arevalo F, Alonso-Díaz MA, FragosoSanchez H, Santamaria VM, Rosario-Cruz R. Prevalence and potential risk factors for amitraz resistance in Boophilus microplus ticks in cattle farms in the State of Yucatan, Mexico. Prev Vet Med 2006; 75(3-4): 280-286. PMid:16730819. http://dx.doi.org/10.1016/j.prevetmed.2006.04.001.

Ryan E, Galvin K, O'Connor TP, Maguire AR, O’Brien NM. Fatty acid profile, tocopherol, squalene and phytosterol content of Brazil, pecan, pine, pistachio and cashew nuts. Int J Food Sci Nutr 2006; 57(3-4): 219 228. PMid:17127473. http://dx.doi.org/10.1080/09637480600768077.

Santos FCC, Vogel SF. Amitraz and cypermethrin resistance ticks Rhipicephalus (Boophilus) microplus in cattle herds located in Rio Grande do Sul from 2005 to 2011. RPCV 2012; 107(581-582): 121-124.

Santos LB, Souza JK, Papassoni B, Borges DGL, Damasceno GA Jr, Souza JME, et al. Efficacy of extracts from plants of the Brazilian Pantanal against Rhipicephalus (Boophilus) microplus. Rev Bras Parasitol Vet 2013a; 22(4): 532-538. PMid:24473878. http://dx.doi.org/10.1590/S198429612013000400013

Sousa CICC. Avaliação da Atividade Antimalárica de Bioprodutos da Bertholletia excelsa H.B.K[Dissertation]. Rondônia: Fundação Universidade Federal de Rondônia Núcleo de Ciências e Tecnologia; 2013.

Tabassum N, Vidyasagar GM. In vitro antimicrobial activity of edible oils against human pathogens causing skin infections. Int J Pharm Sci Res 2014; 5(10): 4493-4498

Tang B, Row KH. Development of gas chromatography analysis of fatty acids in marine organisms. J Chromatogr Sci 2013; 51(7): 599-607. PMid:23377649. http://dx.doi.org/10.1093/chromsci/bmt005.

Venkatachalam M, Sathe SK. Chemical composition of selected edible nut seeds. J Agric Food Chem 2006; 54(13): 4705-4714. PMid:16787018. http://dx.doi.org/10.1021/jf0606959.

Vudriko P, Okwee-Acai J, Tayebwa DS, Byaruhanga J, Kakooza S, Wampande E, et al. Emergence of multi-acaricide resistant Rhipicephalus ticks and its implication on chemical tick control in Uganda. Parasit Vectors 2016; 9(1): 4. PMid:26727991. http://dx.doi.org/10.1186/ s13071-015-1278-3.

Yeom HJ, Kang JS, Kim GH, Park IK. Insecticidal and acetylcholine esterase inhibition activity of apiaceae plant essential oils and their constituents against adults of german cockroach (Blattella germanica). J Agric Food Chem 2012; 60(29): 7194-7203. PMid:22746406. http:// dx.doi.org/10.1021/jf302009w. 